\title{
PENGARUH MODEL PEMBELAJARAN SEARCH, SOLVE,CREATE AND SHARE (SSCS) TERHADAP PEMAHAMAN KONSEP MATEMATIKA SISWA KELAS VIIII SMP NEGERI 1 BANJAR
}

\author{
N. P. E. F. Astuti, G. Suweken, D. Waluyo \\ Jurusan Matematika Universitas Pendidikan Ganesha \\ Singaraja, Indonesia \\ e-mail: erinfebri7@gmail.com,gdsuweken5@gmail.com, \\ waluyo.dk@gmail.com
}

\begin{abstract}
Abstrak
Penelitian ini bertujuan untuk mengetahui pengaruh model pembelajaran Search, Solve, Create, and Share (SSCS) terhadap pemahaman konsep matematika siswa. Jenis penelitian ini adalah eksperimen semu dengan post-test only control group design. Populasi penelitan ini adalah siswa Kelas VIII SMP Negeri 1 Banjar tahun ajaran 2017/2018 sebanyak 11 kelas. Pengambilan sampel dilakukan dengan teknik cluster random sampling. Kemudian dilakukan uji kesetaraan sampel menggunakan uji Anava. Data pemahaman konsep matematika siswa diperoleh melalui tes uraian. Analisis data menggunakan ujit satu ekor yaitu ekor kanan, dengan taraf signifikansi 5\%. Berdasarkan hasil analisis data diperoleh ratarata skor pemahaman konsep matematika kelas eksperimen adalah 33.17 sedangkan pada kelas kontrol adalah 27.79. Hasil pengujian dengan uji-t diperoleh nilai thitung $=3,10$ dan tabel $=1,98$, sehingga thitung $>$

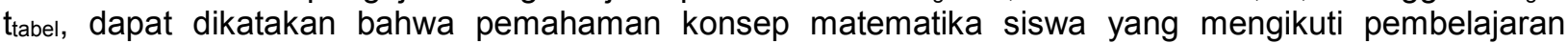
dengan model Search, Solve, Create, and Share (SSCS) lebih baik dari pemahaman konsep matematika siswa yang mengikuti pembelajaran dengan pembelajaran konvensional. Jadi kesimpulannya adalah model pembelajaran Search, Solve, Create, and Share (SSCS) berpengaruh positif terhadap pemahaman konsep matematika siswa.
\end{abstract}

Kata kunci: model pembelajaran Search, Solve, Create, and Share (SSCS), pembelajaran konvensioal, pemahaman konsep matematika.

\begin{abstract}
This research aimed to investigate the effect of SSCS learning model to students' mathematics conceptual understanding. The type of the research was quasi-experimental with post-test only control group design. The population of the research were eighth grade students of SMP Negeri 1 Banjar in the academic year of 2017/2018 which were 11 classes. The sampling was done by cluster random sampling technique. ANOVA test was performed to test the equality of the sample. To get the data of students' mathematics conceptual understanding, an essay test was used. The data analysis used one-tailed t test, which was right tail, with $5 \%$ significance level. Based on the result of data analysis, the average score of mathematics conceptual understanding in the experiment group was 33.17, meanwhile the students in control group got 27.79. The result of the t-test showed that $t_{\text {score }}=3.10$ and table $=1.98$, hence $t_{\text {score }}>$ table. In conclusion, it can be said that the mathematics conceptual understanding of students who learned by Search, Solve, Create and Share (SSCS) model was better than they who learned by conventional learning. The conclusion was that SSCS model gave positive contribution toward the students' mathematics conceptual understanding.
\end{abstract}

Keywords: Search, Solve, Create, and Share (SSCS) learning model, conventional learning, mathematics conceptual understanding.

\section{PENDAHULUAN}

Kualitas pendidikan merupakan salah satu modal penting untuk membantu pembangunan nasional. Hal ini dikarenakan kualitas pendidikan merupakan salah satu faktor yang mempengaruhi kualitas sumber daya manusia. Karena itu, upaya peningkatan kualitas pendidikan di Indonesia dari tahun ke tahun selalu menjadi program pemerintah, salah satu upaya yang telah dilakukan adalah dengan ditetapkannya UU No. 20 Tahun 2003 tentang Sistem Pendidikan Nasional yang menyatakan bahwa pendidikan adalah 
usaha sadar untuk mewujudkan suasana belajar dan pembelajaran agar peserta didik secara aktif mengembangkan potensi dirinya untuk memiliki kekuatan spiritual kegamaan, pengendalian diri, kepribadian, kecerdasan, akhlak mulia, serta keterampilan yang diperlukan dirinya, masyarakat, bangsa, dan negara (Hasbullah: 2005).

Pembelajaran di sekolah meliputi berbagai mata pelajaran, salah satunya adalah matematika. Menurut UndangUndang RI Nomor 20 Tahun 2003 pasal 37 tentang Sistem Pendidikan Nasional, kurikulum pendidikan dasar dan menengah wajib memuat salah satunya mata pelajaran matematika. Matematika merupakan ilmu yang diperoleh melalui penalaran yang dapat dipelajari, dikaji, dan dikerjakan serta merupakan ilmu dasar yang memiliki peranan penting dalam kehidupan (Suherman, 2003). Mengingat pentingnya peranan matematika dalam kehidupan dan pengembangan pengetahuan, sudah sepantasnya penguasaan terhadap matematika mutlak diperlukan serta konsep-konsep matematika harus dipahami dengan tepat dan benar.

Berdasarkan pemaparan tersebut dapat dilihat bahwa orientasi dari pembelajaran matematika salah satunya adalah pemahaman konsep matematika. Hal ini sesuai dengan tujuan utama pembelajaran matematika, seperti yang diungkapkan dalam Permendibud No. 58 Tahun 2016 Tentang Standar Isi Pendidikan Dasar dan Menengah (BSNP, 2016) yaitu Memahami konsep matematika, merupakan kompetensi dalam menjelaskan keterkaitan antarkonsep dan menggunakan konsep maupun algoritma, secara luwes, akurat, efisien, dan tepat dalam pemecahan masalah.

Pemahaman konsep matematika merupakan landasan penting untuk berpikir dalam menyelesaikan permasalahan matematika maupun permasalahan seharihari (Hadi \& Kasum, 2015). Sejalan dengan hal tersebut Hudojo (2003) juga menyatakan bahwa belajar matematika perlu memahami konsep-konsep dan struktur-struktur yang terdapat dalam bahasan yang dipelajari serta mencari hubungan antara konsep dan struktur tersebut. Dengan pemahaman konsep matematika yang baik, siswa akan mudah mengingat, menggunakan, dan menyusun kembali suatu konsep yang telah dipelajari serta dapat menyelesaikan berbagai variasi soal matematika guna menyelesaikan permasalahan dalam kehidupan sehari-hari.

Untuk dapat menanamkan konsep matematika pada peserta didik tidaklah mudah. Hal ini dikarenakan masih banyak siswa yang menganggap bahwa pelajaran matematika adalah pelajaran yang sangat menakutkan dan sulit untuk dipahami. Hudojo (2003:103) mengatakan, "Matematika sebagai ilmu yang menelaah bentuk-bentuk atau struktur-struktur yang abstrak dan hubungan antara hal-hal itu". Matematika mempelajari bentuk dan struktur yang abstrak, sehingga memerlukan proses berpikir dan nalar yang cukup tinggi dalam mempelajarinya. Dikarenakan objek yang dipelajari bersifat abstrak, matematika dianggap sulit, membosankan, dan kurang menarik oleh siswa. Hal seperti ini yang memicu rendahnya pemahaman konsep matematika siswa.

Rendahnya pemahaman konsep siswa Indonesia juga terlihat dari hasil tes PISA (2015). Hasil tes tersebut menunjukan tidak lebih dari $10 \%$ siswa mampu memahami konsep dengan baik, ini berarti $90 \%$ siswa lainnya belum mampu memahami konsep dengan baik. Selain tes yang dilakukan PISA, hasil studi internasional Trends in International Mathematics and Science Student (TIMSS) menyatakan pemahaman konsep matematis siswa Indonesia masih rendah. TIMSS merupakan program dari IAEA (The International Association for the Evaluation of Educational Achievement) yang berfungsi untuk mengetahui perkembangan. Mullis, dkk. (2011) menjelaskan bahwa rata-rata presentase jawaban benar siswa Indonesia pada studi TIMSS tahun 2011 yaitu: 31\% knowing, $23 \%$ apllying, dan $17 \%$ reasoning. Ratarata tersebut jauh dibawah rata-rata presentase jawaban benar internasional, 
yaitu: 49\% knowing, 39\% applying, dan $30 \%$ reasoning.

Dilihat dari hasil nilai rata-rata UN (Ujian Nasional) matematika tingkat SMP yang dikeluarkan oleh Kementerian Pendidikan dan Kebudayaan juga menunjukkan bahwa nilai rata-rata UN Matematika pada jenjang SMP di Indonesia mengalami penurunan setiap tahunnya (Kemendikbud, 2017). Hal ini juga sejalan dengan nilai rata-rata Ujian Nasional (UN) dalam bidang matematika khususnya di Kabupaten Buleleng yaitu dari tahun ajaran 2014/2015 s.d 2016/2017 rata-rata nilai UN masih dibawah angka 47.Tampak bahwa nilai Ujian Nasional (UN) dalam bidang matematika memiliki rata-rata yang cukup rendah.

Tampak bahwa nilai rata-rata Ujian Nasional (UN) dalam bidang matematika rata-rata yang cukup rendah. Hal ini mengindikasikan kemampuan siswa dalam menyelesaikan soal-soal UN masih tergolong rendah. Apabila ditelusuri, salah satu penyebab hal tersebut adalah ketidakmampuan peserta didik dalam menggunakan konsep untuk menjawab soal pengaplikasian dengan berbagai situasi. Dengan kata lain kasus tersebut dipengaruhi oleh pemahaman konsep matematika siswa yang masih rendah.

Hasil-hasil di atas mengindikasikan perlunya terobosan baru dalam pembelajaran matematika yang bisa mengkoneksikan konsep-konsep matematika tersebut, sehingga konsepkonsep itu tertanam kuat pada peserta didik. Pemahaman konsep yang baik akan membantu peserta didik dapat memecahkan permasalahan yang diberikan walaupun dibuat dengan konten dan bentuk yang berbeda. Berdasarkan hal tersebut perlu adanya perencanaan yang baik sebelum melaksanakan pembelajaran. Salah satu perencanaan yang dapat dilakukan adalah dengan memilih suatu model yang dinilai efektif untuk digunakan.

Menurut Rusman (2012:133) "model pembelajaran dapat dijadikan pola pilihan, artinya para guru boleh memilih model pembelajaran yang sesuai dan efisien untuk mencapai tujuan pendidikannya". Model pembelajaran yang mampu menciptakan keaktifan peserta didik di kelas dan melatih peserta didik menggunakan kemampuan berpikir dalam menguasai konsep ilmu melalui langkah-langkah model tersebut adalah Model Pembelajaran Search, Solve, Create, and Share yang selanjutnya disingkat dengan SSCS.

Model Pembelajaran SSCS adalah model pembelajaran yang menekankan pada penggunaan pendekatan saintifik atau berpikir secara sistematis, logis, teratur dan teliti. Tujuannya adalah untuk membantu siswa agar mampu mengkontruksi konsep matematis secara terstruktur dan memahaminya. Model Pembelajaran SSCS menuntut keterlibatan peserta didik dalam setiap fasenya. Adapun fase-fasenya adalah.

a. Search, yaitu fase yang menuntut siswa melakukan pencarian pertanyaan melalui identifikasi kriteria tentang topik yang mereka ingin selidiki.

b. Solve, yaitu fase perencanaan, pendeskripsian konsep, dan penerapan rencana untuk menyelesaikan masalah.

c. Create, yaitu fase mengevaluasi proses berpikir serta mengembangkan dan merumuskan secara kreatif solusi yang telah didapat sehingga dapat mengkomunikasikan hasil dari fase sebelumnya.

d. Share, yaitu fase mengkomunikasikan hasil serta menghasilkan kembali pertanyaan untuk diselidiki.

Pembelajaran dengan model SSCS memiliki langkah-langkah yang hamppir sama dengan tahapan pada pembelajaran 5M (Mengamati, Menanya, Mengumpulkan data, Mengasosiasi, Mengkomunkasikan). Adapun perbedaan yang paling menonjol antara model pembelajaran SSCS dan pembelajaran $5 \mathrm{M}$ adalah pada fase create. Pada fase create, dimana siswa dituntut untuk menggabungkan, mengembangkan dan merumuskan solusi permasalahan secara kreatif dengan terstruktur dan sistematis agar dapat dikomunikasikan pada tahapan selanjutnya. Dengan kata lain pada model pembelajaran SSCS siswa melaksanakan evaluasi terhadap solusi yang diperoleh sebanyak dua kali yaitu 
dilaksanakan pada kelompok kecil dan kelompok besar saat fase share, sehingga hasil yang diperoleh dapat mendekati simpulan yang diharapakan dan mencapai tujuan pembelajaran. Sedangkan pada pembelajaran $5 \mathrm{M}$ solusi yang diperoleh hanya dievaluasi pada akhir pembelajaran.

Secara khusus masing-masing fase dari model pembelejaran SSCS memiliki hubungan untuk meningkatkan pemahaman konsep matematika siswa. Pada fase search siswa dituntun untuk dapat menemukan contoh dari konsep yang akan dibahas sehingga, dapat membedakan antara contoh dan bukan contoh dari konsep yang akan dibahas pada proses pembelajaran. Selanjutnya pada fase solve siswa dituntut untuk membedakan konsep yang diperlukan dan tidak diperlukan dalam proses penyelesaian masalah sehingga dapat menggunakan konsep pada situasi dan kondisi yang berbeda.

Kemudian fase yang paling kongkrit adalah fase create, pada fase ini siswa dituntut untuk dapat mengevalusi dan merumuskan hasil yang telah diperoleh pada fase solve sehingga dapat dikomunikasikan pada fase share. Pada fase share kemampuan yang dituntut adalah siswa dapat membahasakan sendiri konsep yang telah diidentifikasi. Berdasarkan hubungan tersebut model pembelajaran SSCS diduga dapat meningkatkan pemahaman konsep matematika siswa.

Hal tersebut didukung oleh penelitian yang dilakukan Satriawan (2015) bahwa pembelajaran matematika dengan model SSCS mampu meningkatkan prestasi dan kemampuan penalaran matematis siswa, tetapi tidak ada peningkatan motivasi belajar dari siswa. Pemahaman konsep yang baik sangat diperlukan untuk meningkatkan prestasi belajar dan kemampuan penalaran matematis, karena pada prestasi belajar dan kemampuan penalaran matematis siswa dituntut lebih mengembangkan kemampuan dalam menerapkan konsep-konsep dan penalaran dalam penyelesaian soal yang secara tidak langsung menuntut siswa untuk memahami konsep terlebih dahulu. Sehingga dapat dilihat keterkaitan antara prestasi belajar dan kemampuan penalaran matematis dengan pemahaman konsep.

Berdasarkan deskripsi yang telah dikemukakan di atas, model pembelajaran SSCS diduga berpengaruh positif terhadap pemahaman konsep matematika siswa. Namun belum ada literature atau hasil penelitian yang secara tegas menyatakan pengaruh model pembelajaran SSCS dapat mempengaruhi atau meningkatkan pemahaman konsep matematika siswa. Untuk mendapatkan bukti secara empiris tentang hal tersebut, maka penulis tertarik untuk melakukan suatu penelitian dengan judul "Pengaruh Model Pembelajaran Search, Solve, Create, and Share (SSCS) terhadap Peningkatan Pemahaman Konsep Matematika Siswa Kelas VIII SMP Negeri 1 Banjar".

Berdasarkan latar belakang masalah yang telah diuraikan, dapat diperoleh sebuah rumusan masalah sebagai berikut. "Apakah penerapan model pembelajaran SSCS berpengaruh positif terhadap pemahaman konsep matematika siswa Kelas VIII SMP Negeri 1 Banjar?".

Tujuan yang ingin dicapai dari penelitian ini adalah untuk menunjukkan bahwa pemahaman konsep matematika siswa yang mengikuti pembelajaran dengan model SSCS lebih baik dari pada pemahaman konsep matematika siswa yang mengikuti pembelajaran konvensional.

\section{METODE}

Penelitian ini merupakan eksperimen semu (quasi experiment). Penelitian semu dapat digunakan untuk melihat pengaruh yang ditimbulkan dari perlakuan berbeda yang diberikan pada masing-masing kelompok, dimana peneliti tidak dapat mengontrol semua variabel dan kondisi eksperimen secara ketat (Sugiyono, 2015). Penelitian ini bertujuan untuk mengetahui pengaruh model pembelajaran SSCS terhadap pemahaman konsep matematika siswa Kelas VIII SMP Negeri 1 Banjar.

Populasi dalam penelitian ini adalah siswa Kelas VIIII SMP Negeri 1 Banjar tahun ajaran 2018/2019. Jumlah siswa 
adalah 397 orang siswa yang tersebar ke dalam 11 kelas, yaitu kelas VIII.A, VIII.B, VIII.C, VIII.D, VIII.E, VIII.F, VIII.G, VIII.H, VIII.I, VIII.J, dan VIII.K.

Penentuan sampel dalam penelitian ini dilakukan dengan teknik cluster random sampling yaitu sampel diambil dari kelompok-kelompok kelas secara acak karena tidak memungkinkan melakukan pengacakan individu sehingga menggunakan kelas yang sudah ada.

Setelah melakukan pengambilan kelas sebagai sampel penelitian, memperoleh hasil yaitu terpilihnya empat kelas sebagai sampel yaitu kelas VIII.A, VIII.C, VIII.D, dan VIII.E. Kemudian dilakukan penyetaraan terhadap sampel penelitian untuk mengetahui ada tidaknya perbedaan rata-rata skor kemampuan awal matematika siswa dengan menggunakan uji ANAVA satu jalur. Data yang digunakan dalam pengujian kesetaraan kelas dalam kelompok sampel adalah nilai ulangan umum matematika siswa semester ganjil tahun ajaran 2016/2017.

Sebelum diuji kesetaraannya menggunakan uji ANAVA satu jalur, sampel terlebih dahulu diuji normalitas sebaran datanya dan homogenitas variansnya. Uji normalitas sebaran data populasi menggunakan Uji Lilliefors. Setelah dianalisis, dapat disimpulkan bahwa data nilai ulangan umum matematika siswa dari empat kelas tersebut berasal dari populasi berdistribusi normal. Kemudian setelah uji normalitas, dilanjutkan dengan uji homogenitas menggunakan uji Levene. Hasil yang diperoleh adalah data nilai ulangan umum matematika siswa di kelas sampel memiliki varians yang homogen.

Selanjutnya dilakukan perhitungan untuk menguji kesetaraan sampel menggunakan uji ANAVA satu jalur (Uji F) Hasil uji kesetaraan dengan menggunakan uji ANAVA satu jalur yang diperoleh $F_{\text {hitung }}=$ 0.730 Adapun nilai $F_{\text {tabel }}$ dengan $\mathrm{dk}$ pembilang $=4-1=3 \mathrm{dan} \mathrm{dk}$ penyebut $=$ $141-4=137$, pada taraf signifikasi 0,05 adalah 2,671. Apabila dibandingkan, nilai $F_{\text {hitung }}$ lebih kecil dari nilai $F_{\text {tabel }}$ atau $F_{\text {hitung }}<$ $F_{\text {tabel. }}$ Maka keempat kelas sampel tersebut setara. Selanjutnya, dari empat kelas sampel yang setara tersebut akan diundi kembali untuk menentukan kelompok eksperimen dan kelompok kontrol dimana terpilih kelas VIII.A dan VIII.D sebagai kelas eksperimen dan VIII.C dan VIII.E sebagai kelas kontrol

Penelitian ini melibatkan variabel bebas (independent variable) dan variabel terikat (dependent variable). Adapun variabel bebas dalam penelitian ini adalah model pembelajaran dimana model pembelajaran SSCS diterapkan pada kelas eksperimen dan model pembelajaran kooperatif pada kelas kontrol sedangkan variabel terikatnya adalah pemahaman konsep matematika siswa.

Desain yang digunakan dalam penelitian ini adalah "Post Test Only Control Group Design". Terdapat dua kelompok yang menjadi sampel penelitian yaitu kelompok eksperimen dan kelompok kontrol. Instrumen yang digunakan dalam penelitian ini berupa tes. Data yang akan dikumpulkan pada penelitian ini berupa skor pemahaman konsep matematika siswa, yang dikumpulkan melalui tes pemahaman konsep matematika. Tes pemahaman konsep matematika yang akan digunakan adalah tes essay. Digunakannya tes essay ini dengan alasan dapat diketahui bagaimana siswa menyatakan konsep dengan kata-kata sendiri, mengidentifikasi contoh dan bukan contoh dari suatu konsep, dan menuangkan pemikirannya secara tertulis terhadap jawaban dari permasalahan yang diberikan.

Untuk memudahkan

pemeriksaan dan meminimalisir subjektivitas, dibuat rubrik penskoran untuk tes pemahaman konsep matematika siswa. Pada penelitian ini rubrik yang digunakan adalah dari NCTM pada tahun 2000.

Setelah instrumen tersusun, maka dilakukan uji coba instrumen yang selanjutnya dianalisis dengan uji validitas dan uji reliabilitas. Sebelum di uji cobakan, peneliti menguji instrumen pada pakar yaitu dilakukan dengan meminta bantuan dua orang dosen di lingkungan Jurusan Pendidikan Matematika yang bertujuan untuk mengetahui validitas isi instrumen. 
Untuk menguji validitas butir soal essay digunakan koefisien korelasi productmoment dari Carl Pearson (Candiasa, 2010a:38). Data yang digunakan adalah data yang diperoleh dari hasil tes uji coba yang diberikan kepada sampel diluar sampel penelitian.

Uji coba penelitian ini dilakukan di kelas VIII.A2 dan VIII,B2 SMP Negeri 4 Singaraja. Dimana jumlah soal yang diujicobakan adalah delapan butir soal. Dari hasil uji coba validitas tes diperoleh tujuh butir soal yang valid. ketujuh soal tersebut diuji reliabilitasnya. Melalui perhitungan diperoleh bahwa $r_{11}=0,66$ dimana dari kriteria yang telah ditetapkan maka derajat reliabilitas tes tergolong tinggi, sehingga soal-soal tersebut layak untuk digunakan. Dari 7 butir soal yang valid dan reliabel dipilih 5 soal yang akan digunakan sebagai tes kemampuan pemahaman konsep matematika siswa, karena kelima soal tersebut telah menangkup keseluruhan materi yang diajarkan.

Sebelum dilaksanakan pengujian untuk memperoleh simpulan, data yang diperoleh harus diuji normalitasnya. Uji normalitas untuk skor kemampuan komunikasi matematika siswa digunakan uji Lilliefors. Pada pengujian normalitas data dengan uji Lilliefors, dicari selisih frekuensi sebaran data dengan frekuensi kumulatif sampai batas tiap-tiap data.

Uji homogenitas varians untuk kedua kelompok sampel digunakan Uji Levene dengan menggunakan rumus sebagai berkut:

$$
W=\frac{(N-k) \sum_{i=1}^{k} n_{i}\left(\overline{d_{i}}-\bar{d}\right)^{2}}{(k-1) \sum_{i=1}^{k} \sum_{j=1}^{n}\left(d_{i j}-\overline{d_{i}}\right)^{2}}
$$

(Candiasa, 2010b:282)

Setelah diuji normalitas dan homogenitas data selanjutnya akan dilakukan uji hipotesis penelitian. Jika data berdistribusi normal dan homogen maka pengjujian hipotesis nol digunakan uji- $t$ dengan taraf signifikansi $5 \%$ yang dirumuskan

$$
t_{h i t}=\frac{\bar{Y}_{1}-\bar{Y}_{2}}{\sqrt{\frac{s^{2}}{n_{1}}+\frac{s^{2}}{n_{2}}}}
$$

dengan:

$$
\begin{aligned}
& s^{2}=\frac{\left(n_{1}-1\right) s_{1}^{2}+\left(n_{2}-1\right) s_{2}^{2}}{\left(n_{1}+n_{2}-2\right)} \\
& s_{1}^{2}=\frac{\Sigma\left(x_{1}-\bar{x}_{1}\right)^{2}}{n_{1}-1} ; \quad s_{2}^{2}=\frac{\Sigma\left(n_{1}-\bar{x}_{2}\right)^{2}}{n_{1}-1}
\end{aligned}
$$

(Candiasa, 2010b:58)

\section{HASIL DAN PEMBAHASAN}

Data mengenai skor pemahaman konsep matematika siswa diperoleh dari post-test yang diberikan kepada kedua kelompok sampel dapat dilihat pada tabel berikut ini.

Tabel 1.Rangkuman analisis data skor pemahaman konsep matematika siswa

\begin{tabular}{|c|c|c|}
\hline \multirow{2}{*}{ Variabel } & \multicolumn{2}{|c|}{ Sampel } \\
\cline { 2 - 3 } & $\begin{array}{c}\text { Kelas } \\
\text { Eksperimen }\end{array}$ & $\begin{array}{c}\text { Kelas } \\
\text { Kontrol }\end{array}$ \\
\hline $\mathrm{N}$ & 70 & 71 \\
\hline $\bar{X}$ & 33.17 & 27.79 \\
\hline $\mathrm{SD}$ & 10.55 & 10.10 \\
\hline
\end{tabular}

Keterangan:

$N$ : Banyak siswa

$\bar{X}$ : Rata-rata skor kemampuan komunikasi matematika siswa

$S D$ : Standar Deviasi

Berdasarkan tabel tersebut terlihat bahwa rata-rata skor pemahaman konsep matematika siswa pada kelas eksperimen lebih tinggi daripada rata-rata skor pemahaman konsep matematika siswa kelas kontrol.

Untuk mengetahui apakah pemahaman konsep matematika siswa yang mengikuti model pembelajaran SSCS lebih baik daripada pemahaman konsep matematika yang mengikuti pembelajaran konvensional maka perlu dilakukan pengujian terhadap $\mathrm{H}_{0}$. Sebelum uji hipotesis dilakukan, terlebih dahulu dilakukan pengujian terhadap normalitas 
dan homogenitas varians skor tes pemahaman konsep matematika siswa.

Hasil uji normalitas data pemahaman konsep matematika siswa pada kelas kontrol diperoleh $L_{\text {hitung }}=0,148$ (untuk dk $=\mathrm{n}=71$ pada taraf signifikansi $5 \%$ ) diperoleh $\quad L_{\text {zabal }}=0,157$. Karena $L_{\text {hitung }}<L_{\text {zabal }}, \quad$ maka sebaran data pemahaman konsep matematika siswa pada kelas kontrol berdistribusi normal. Sedangkan, hasil uji normalitas data pemahaman konsep matematika siswa pada kelas eksperimen diperoleh $L_{\text {hitung }}=0,091$ (untuk $\mathrm{dk}=\mathrm{n}=70$ pada taraf signifikansi $5 \%$ diperoleh $L_{\text {tabel }}=0,153$. Karena $L_{\text {hitung }}<L_{\text {tabel }}$, maka sebaran data pemahaman konsep matematika siswa pada kelas eksperimen berdistribusi normal. Jadi dapat disimpulkan kedua kelas sampel beridistribusi normal.

$$
\text { Selanjutnya dilakukan uji }
$$

homogenitas menggunakan Uji Levene. Hasil uji homogenitas varians sebaran data skor pemahaman konsep matematika siswa untuk kedua kelompok dapat dilihat pada tabel berikut.

Tabel 2.Rangkuman hasil uji Homogenitas varians skor pemahaman konsep matematika siswa

\begin{tabular}{|c|c|c|c|}
\hline $\begin{array}{c}\text { Kelompok } \\
\text { Sampel }\end{array}$ & $\mathbf{W}$ & $F_{\text {tawsi }}$ & Keterangan \\
\cline { 1 - 1 } Eksperimen & 0.26 & 3.91 & Homogen \\
\cline { 1 - 2 } Kontrol & 0.26 & Hom
\end{tabular}

Dari tabel tersebut, dapat dilihat bahwa W lebih kecil daripada $F_{\text {tabel. }}$

Dengan demikian $\mathrm{H}_{0}$ diterima dan hal tersebut berarti data pemahaman konsep matematika siwa pada kelas sampel mempunyai varians yang homogen.

Pengujian normalitas dan homogenitas menunjukkan bahwa data sampel memiliki sebaran data yang normal dan memiliki varians yang homogen sehingga untuk menguji hipotesisnya digunakan uji-t satu ekor. Hasil perhitungan diperoleh nilai $t_{\text {hitung }}$ adalah 3.10 dan nilai

$t_{\text {tabel }}$ adalah 1.98. Apabila dibandingkan, nilai $t_{\text {hitumg }}$ lebih dari nilai $t_{\text {tabel }}$. Dengan

demikian $\mathrm{H}_{0}$ ditolak. Hal ini berarti pemahaman konsep matematika siswa yang mengikuti Model Pembelajaran SSCS lebih baik daripada pemahaman konsep matematika siswa yang mengikuti pembelajaran konvensional.

Hal ini dikarenakan pembelajaran menggunakan model SSCS memberi kesempatan kepada siswa untuk belajar lebih aktif berdiskusi dalam menyelesaikan suatu masalah, kreatif, terlatih mengunakan kemampuan berpikir dalam menguasai konsep ilmu dan aktif mencari informasi terkait materi yang akan berdampak pada meningkatnya pemahaman konsep matematika siswa. Pada model pembelajaran SSCS, langkah-langkah yang terdapat di dalamnya memungkinkan siswa untuk belajar lebih aktif dan kreatif. Terdapat empat langkah dalam model pembelajaran ini, (1) Search (2) Solve, (3) Create, dan (4) Share.

Penerapan pembelajaran matematika dengan model pembelajaran kooperatif tipe SSCS diawali dengan membagi peserta didik dalam kelompok-kelompok kecil yang terdiri dari 3-4 peserta didik, kemudian dilanjutkan fase search, pada fase ini setiap anggota kelompok berdiskusi untuk mengidentifikasi kriteria agar dapat menetapkan masalah, mengembangkan dan membuat pertanyaan mengenai topik yang diselidiki sesuai dengan LKS yang telah diberikan. Pada fase ini juga setiap anggota kelompok dapat mencari perkiraan jawaban pada literatur pembelajaran. Pada fase ini terlihat bahwa setiap peserta didik mampu membedakan yang mana yang merupakan contoh dari topik yang dibahas dan mana yang bukan. Hal tersebut terlihat dari hasil identifikasi masalah yang mereka lakukan.

Dilanjutkan dengan fase solve. Pada fase ini peserta didik berpusat pada permasalahan spesifik yang ditetapkan pada fase Search dan mengharuskan peserta didik untuk menghasilkan dan menerapkan rencana mereka serta mendeskripsikan konsep yang digunakan untuk memperoleh suatu jawaban. Selain 
itu, pada fase solve setiap siswa harus mencari penyelesaiannya masing-masing terhadap masalah pada LKS yang akan didiskusikan dalam kelompok, sehingga setiap siswa memiliki tanggung jawab untuk menyelesaikan masalah pada LKS dan kecendrungan keaktifan di kelas hanya didominasi oleh sebagian siswa dapat dihindari. Selama peneliti melakukan pengamatan di kelas eksperimen yaitu Kelas VIII A dan VIII D pada tahap solve siswa terlihat berpartisipasi aktif dalam proses pembelajaran karena setiap siswa memiliki tanggung jawab yang sama. Dari hal tersebut terlihat masing-masing siswa mampu membedakan contoh dan bukan contoh serta dapat mengaplikasikan konsep yang didapat dalam proses penyelesaian masalah.

Kemudian fase create, siswa berdiskusi dan mendengarkan penyelesaian masalah pada LKS dari masing-masing anggota kelompok, anggota dalam kelompok bersama-sama membentuk jawaban terbaik dari jawaban-jawaban yang telah disampaikan oleh setiap anggota dalam kelompok. Kegiatan ini membiasakan siswa mengembangkan hasil pemikirannya, ideide ataupun gagasan-gagasan yang mengarah pada penyelesaian dari permasalahan yang dibahas. Terlihat pada kegiaan ini setiap peserta didik dapat mengkomunikasikan hasil yang diperolehnya kepada anggota kelompok dengan menggunakan kata-kata mereka sendiri sehingga dapat diterima dengan baik oleh setiap anggota kelompok. Selain hal itu, dalam proses diskusi perserta didik dapat mengkaji kembali hasil pada fase Solve dan memilah contoh dan bukan contoh yang tepat sehingga dapat mengaplikasikan konsep untuk mencari solusi terbaik yang hasilnya akan dikomunikasikan pada fase Share.

Kemudian dilanjutkan dengan tahap share yang merupakan tahap terakhir dalam model pembelajaran SSCS. Setelah terbentuk jawaban terbaik dari setiap kelompok, perwakilan suatu kelompok diminta untuk mempresentasikan jawaban mereka di depan kelas, dan kelompok lainnya menanggapi jawaban dari kelompok penyaji. Fase ini memberikan kesempatan bagi peserta didik untuk berinteraksi, mengemukakan pendapat, meminta pendapat, serta menerima umpan balik dari teman atau kelompok lain dalam diskusi kelas. Dari proses yang dilakukan pada fase ini siswa mampu menunjukan kemampuan mereka dalam menyatakan ulang konsep dari hasil penyelesaian masalah yang mereka telah bahas dalam kelompok.

Sedangkan pada fase ini guru bertindak sebagai fasilitator dalam diskusi dan mengoreksi jika terdapat jawaban yang keliru. Setelah melakukan diskusi, siswa diminta untuk menarik kesimpulan terhadap materi yang telah diajarkan dan peran guru sangat dibutuhkan untuk memperoleh kesepakatan agar tidak menyimpang dari tujuan pembelajaran yang ingin dicapai. Kemudian guru menginformasikan materi selanjutkan dengan cara memberikan pertanyaan pancingan terkait hubungan materi pada saat ini dengan materi selanjutnya agar muncul rasa ingn tahu dan pertanyaan-pertanyaan dari siswa sehingga siswa ingin menyiapkan dan mencari literatur-literatur penunjang untuk pertemuan berikutnya.

Berdasarkan pengamatan peneliti, fase search dan create merupakan fase yang paling mempengaruhi pemahaman konsep matematika siswa, karena pada tahap ini siswa saling bertukar pikiran terkait cara menyelesaikan permasalahan dan saling mendiskusikan hasil pekerjaan mereka yang akan menambah pengetahuan yang dimilikinya. Mereka juga mengkomunikasikan hasil pekerjaannya yang mengindikasikan bahwa mereka memahami apa yang mereka telah kerjakan. Selain itu, merngoreksi jawaban yang telah dibuat akan membuat siswa lebih mengerti mengenai apa yang dipelajari, dengan itu tahap ini memiliki kontribusi yang besar meningkatkan pemahaman konsep matematika siswa.

Hal ini sejalan dengan penelitian Satriawan (2015) yang menyatakan bahwa model pembelajaran SSCS menunjukkan peningkatan pada prestasi dan kemampuan penalaran matematis peserta didik dan 
mampu membiasakan siswa untuk melatih kemampuan yang dimiliki siswa sehingga nantinya siswa bisa lebih kreatif dalam menyusun dan menyelesaikan permasalahan. Dengan demikian maka pemahaman konsep juga akan meningkat.

Berbeda halnya dengan pembelajaran konvensional, pembelajaran konvensional kurang menekankan keaktifan siswa dalam proses pembelajaran karena masih didominasi oleh siswa-siswa yang pandai. Terdapat beberapa tahap dalam pembelajaran konvensional yaitu: Pada awal pembelajaran guru memberikan salam dan menyampaikan materi kepada seluruh siswa. Kegiatan ini masih didominasi oleh guru. Kemudian guru membagikan LKS kepada siswa dan dikerjakan secara berkelompok dengan jumlah anggota kelompok empat sampai lima orang. Siswa menyelesaiakan permasalahan pada LKS, namun pada kegiatan ini tidak semua siswa aktif dalam berdiskusi dan hanya didominasi oleh siswa yang pandai, hal ini dipengaruhi oleh sebagian besar anggota kelompok yang merasa kurang dan bergantung pada siswa yang pandai, dan enggan untuk berpendapat serta hanya beberapa siswa yang mau bertanya ketika mengadapi masalah dalam pengerjaan LKS.

Setelah selesai mengerjakan LKS, siswa diberikan kesempatan untuk mempresentasikan hasilnya. Tetapi rasa tanggung jawab siswa terhadap hasil diskusi tidak menyebar ke setiap anggota kelompok. Peran guru adalah untuk meluruskan pemahanan konsep yang keliru. Kemudian guru memberikan kuis/tes secara berkelompok dan memberikan penghargaan kepada tim yang menonjol atau berprestasi. Berdasarkan pengamatan peneliti, pada saat diskusi kelompok terlihat banyak anggota kelompok yang hanya menunggu jawaban temannya tanpa ikut berpartisipasi dalam diskusi. Selain itu, kecendrungan munculnya topik yang menyimpang dari proses pembelajaran lebih tinggi akibat kegiatan diskusi dalam kelompok didominasi oleh beberapa orang. Ini juga disebababkan oleh tidak adanya penyebaran tanggung jawab ke setiap anggota kelompok. Oleh karena itu, upaya peningkatan pemahaman konsep matematika siswa masih kurang optimal.

Secara umum, pelaksanaan pembelajaran dengan model pembelajaran SSCS dapat berjalan baik dan sesuai rencana. Walaupun demikian, dalam pelaksanaannya di kelas tidak luput dari adanya kendala-kendala. Adapun kendalakendala yang dihadapi adalah sebagai berikut.

1. Minat baca atau mencari beragai literatur pembelajaran masih kurang, sehingga peserta didik dominan hanya belajar berdasarkan LKS dan buku pegangan yang diberikan oleh sekolah.

2. Siswa merasa kebingungan saat model ini pertama kali diterapkan sehingga siswa memerlukan waktu untuk terbiasa. Oleh karena itu, diperlukan upaya ekstra diawal pembelajaran agar maksud model pembelajaran dapat dipahami siswa.

3. Pada saat perwakilan kelompok diminta untuk mempresentasikan hasil diskusi di depan kelas, siswa masih terlihat malu-malu dan kurang kritis dalam menyampaikan kepada siswa lain. Pada awal pertemuan hanya sedikit siswa yang berani mengajukan pertanyaan.

Namun kendala-kendala tersebut dapat ditangani dengan baik. Kendala-kendala tersebut dapat ditangani dengan menginformasikan materi selanjutnya pada setiap akhir pembelajaran sehingga siswa lebih siap dalam mengembangkan pertanyaan-pertanyaan dan memiliki lebih banyak refrensi dalam menyelesaikan masalah. Kemudian, pada setiap awal pertemuan guru harus mengingatkan kembali tahapan-tahapan pembelajaran yang harus dilakukan oleh siswa. Yang terakhir adalah dengan memberikan motivasi kepada siswa dengan memberikan petunjuk berupa pernyataan atau pertanyaan yang mebuat siswa terpacu lebih aktif dalah tahap diskusi. Selain itu, dengan mewajibkan setiap kelompok mengajukan pertanyaan pada awal-awal pertemuan akan memberikan tanggung jawab kepada siswa untuk bertanya sehingga siswa akan semakin terpacu 
untuk memahami materi dan pada akhirnya mendorong siswa lebih aktif mengajukan pertanyaan.

Berdasarkan hasil pengujian hipotesis dan uraian di atas, dapat dilihat bahwa model pembelajaran SSCS berpengaruh positif terhadap pemahaman konsep matematika siswa. Hal ini dibuktikan dengan hasil posttest yang menunjukkan bahwa pemahaman konsep matematika siswa yang mengikuti pembelajaran dengan model pembelajaran SSCS lebih baik daripada siswa yang mengikuti pembelajaran konvensional.

\section{SIMPULAN DAN SARAN}

Berdasarkan pembahasan hasil penelitian dan hasil uji hipotesis, dapat diambil simpulan bahwa pemahaman konsep matematika siswa yang mengikuti pembelajaran dengan model Search, Solve, Create and Share (SSCS) lebih baik daripada pemahaman konsep matematika siswa yang mengikuti pembelajaran konvensional. Oleh karena itu, model pembelajaran Search, Solve, Create and Share (SSCS) berpengaruh positif terhadap pemahaman konsep matematika siswa kelas VIII SMP Negeri 1 Banjar.

Berdasarkan hasil penelitian yang diperoleh, peneliti melalui tulisan ini mengajukan beberapa saran. Adapun saran-saran yang dapat disampaikan adalah sebagai berikut. Kepada praktisi pendidikan matematika, khususnya guru mata pelajaran matematika diharapkan untuk menerapkan model pembelajaran SSCS sebagai salah satu alternatif pembelajaran dalam kegiatan pembelajaran di kelas mengingat memberikan pengaruh positif terhadap pemahaman konsep matematika siswa.

Penelitian ini dilakukan pada populasi dan materi pembelajaran yang terbatas. Para peneliti lain disarankan untuk melakukan penelitian dengan pembelajaran ini dengan populasi yang lebih besar dan materi pembelajaran yang lebih luas untuk mengetahui pengaruh pembelajaran ini dalam pembelajaran matematika secara lebih mendalam.

\section{DAFTAR PUSTAKA}

Ali, Muhamad. 1985. Penelitian Kependidikan Prosedur \& Strategi. Bandung: Angkasa.

Amelia, Lia. 2015. Pengaruh Model Pembelajaran Search, Solve, Create, and Share (SSCS) Terhadap Hasil Belajar Siswa pada Konsep Fluida Statis. Skripsi Sarjana Kependidikan Universitas Islam Negeri Syarif Hidayatullah. Jakarta. Tersedia pada http://repository.uinjkt.ac.id/dspace/bit stream/

123456789/29576/3/LIA\%20AMELIAFITK.pdf (diakses pada tanggal 2 Januari 2018)

Arikunto, S. 2002. Dasar-dasar Evaluasi Pendidikan. Jakarta: Bumi Aksara.

Arsyad, Ahzar. 2006. Media Pembelajaran. Jakarta: RajaGrafindo Persada.

BSNP. 2016. Permendikbud No 21 tentang Tentang Standar Isi Pendidikan Dasar dan Menengah. 2016. Tersedia pada htps://BSNP-Indonesia.org/standar-isi/ (diakses tanggal 23 Juni 2018)

Candiasa, I Made. 2010a. Pengujian Instrumen Penelitian Disertai Aplikasi ITEMAN dan BIGSTEP. Singaraja: Unit Penerbitan Universitas Pendidikan Ganesha.

-----. 2010b. Statistik Univariat dan Bivariat Disertai Aplikasi SPSS. Singaraja: Unit Penerbitan Universitas Pendidikan Ganesha.

Depdiknas. 2003. Undang-Undang No 20 Tahun 2003 tentang Sistem Pendidikan Nasional. 2003. Tersedia pada htps://jatim.kemenag.go/file/dokumen/u u203.pdf (diakses tanggal 23 Juni 2018)

Hadi, Sutarto \& Maidatina Umi Kasum. 2015. Pemahaman Konsep Matematika Siswa SMP melalui Penerapan Model Pembelajaran Kooperatif Tipe Memeriksa Berpasangan (Pair Checks). Jurnal Jurusan Pendidikan Matematika Universitas Lambung Mangkurat Vol.3, No.1. Tersedia pada: http://ppjp.unlam.ac.id/journal/index.php /edumat/article/view/630 (diakses, 8 Januari 2018).

Hamzah, Ali. 2014. Evaluasi Pembelajaran Matematika. Jakarta: Rajawali Pers. 
Harmalik, Oemar. 2005. Pendidikan Guru. Jakarta: Bumi Angkasa.

Hasbullah. 2005. Dasar-Dasar IImu Pendidikan. Jakarta: PT.Raja Grafindo Persada

Hudojo, H. 2003. Common Textbook: Pengembangan Kurikulum dan Pembelajaran Matematika. Malang: IMSTEP

Kementerian Pendidikan dan Kebudayaan. 2017. Rekap Hasil Ujian Nasional (UN) Tingkat Sekolah. Tersedia pada https://puspendik.kemdikbud.go.id/hasilun/ (diakses pada 1 Maret 2018).

Kilpatrick, Swafford, \& Findell. 2001. "Helping Children Learn Mathematics". Tersedia pada:

http://www.nap.edu/catalog/9822.html.

Diakses, 8 Januari 2018.

NCTM. 2000. Principle and Standards for School Mathematic. Virginia: NCTM.

Mullis, dkk. 2011. TIMSS 2011 Asses-ment framework. Chesnut Hills: Boston College.

Pemkab Buleleng. 2017. Laporan Hasil Ujian Nasional. Tersedia pada https://bulelengkab.go.id/assets/bankdat a/Hasil\%20Ujian\%20Nasional\%20Kabu paten $\% 20$ Buleleng $\% 20$ tahun $\% 202016$ 2017\%20(\%20IIUN\%20)_898382 .pdf (diakses pada 1 Maret 2018)

Pindari, D. P. 2015. Pengaruh Penerapan Blended Learning Berbasis Whiteboard Animation Video terhadap Prestasi Belajar Matematika Siswa Kelas VII Non Unggulan SMP Negeri 2 Singaraja. Skripsi (tidak diterbitkan). Jurusan Pendidikan Matematika, Universitas Pendidikan Matematika.

Raehanah. 2013. Pebelajaran Kimia Menggunakan Model Problem Solving Tipe Search Solve Create and Share (SSCS) dan Cooperative Problem Solving (CPS) ditinjau dari Kemampuan Berpikir Kritis dan Kemampuan Matematis. Tesis Master Kependidikan Universitas Sebelas Maret. Surakarta. Tersedia pada: https://digilib.uns.ac.id/dokumen/detail I 34540/Pembelajaran-KimiaMenggunakan-Model-ProblemSolving-Tipe-Search-Solve-Create-
And-Share-SSCS-Dan-CooperativeProblem-Solving-Cps-Ditinjau-DariKemampuan-Berpikir-Kritis-DanKemampuan-Matematis. tanggal 2 Januari 2018)

Rahmawati, Junaedi, dan Kurniasih. 2013. Keefektifan Model Pembelajaran SSCS Berbantuan Kartu Masalah Terhadap Kemampuan Pemecahan Masalah Siswa. Jurnal Pendidikan Matematika Universitas Pendidikan Ganesha. Vol 2 No. 3. Diakses pada https://journal.unnes.ac.id/artikel_sju/u jme/3447 (diakses pada 2 Januari 2018)

Rusman. 2012. Model-model Pembelajaran Mengembangkan Profesionalisme Guru. Jakarta: PT Rajagrafindo Persada, Cet, ke-5.

Satriawan, Rody. 2015. Pengaruh Model Pembelajaran Search, Solve, Create, and Share (SSCS) pada Materi Pokok Persamaan Linear Dua Variabel terhadap Prestasi, Kemampuan Penalaran Matematis, dan Motivasi Belajar Siswa SMP. Tesis Master Kependidikan Universitas Negeri Yogyakarta. Tersedia pada: http://eprints.uny.ac.id/29416/

(diakses pada tanggal 7 Januari 2018)

Sudjana. 1996. Metode Statistika.Bandung: Tarsito.

Suherman, E., dkk. 2003. Strategi Pembelajaran Matematika Kontemporer. Bandung: JICA.

Sukardi. 2015. Evaluasi Pendidikan: Prinsip \& Oprasionalnya. Jakarta: Bumi Aksara.

Suminar, E. P. 2010. Upaya Meningkatkan Pemahaman Konsep Matematika Siswa dengan Pembelajaran Kooperatif Tipe Problem Based Learning dalam Pembelajaran Matematika Siswa Kelas IX SMPN 1 Pacitan. Skripsi (tidak diterbitkan). Jurusan Pendidikan Matematika, FMIPA Universitas Negeri Yogyakarta.

Sugiyono. 2015. Metode Penelitian Pendidikan (Pendekatan Kuantitatif, Kualitatif, dan R\&D). Bandung: Alfabeta. 
Jurnal Pendidikan Matematika Undiksha, Volume IX No 2, Agustus 2018 e-ISNN:2599-2600; p-ISNN: 2613-9677

Warmini, Agung dan Sumantri. 2013. Pengaruh Model Pembelajaran SSCS Berbantuan Media Visual Terhadap Hasil Belajar Matematika Siswa Kelas IV SD di Gugus VII Kecamatan Busungbiu. Jurnal Pendidikan Matematika Universitas Pendidikan Ganesha. Tersedia pada https://ejournal.undiksha.

ac.id/index.php/JJPGSD/article/view/6 92 (diakses pada 2 Januari 2018) 